Biorheology Vol. 15, pp. 355-356.

Pergamon Press Ltd. 1978. Printed in Great Britain

\title{
PREFACE AND EDITORIAL
}

This double issue of Biorheology, comprising issues 5 and 6 of volume 15 , is dedicated to my dear friend Maurice Joly, the fifth recipient of the Poiseuille Gold Medal Award. It is the highest honor by the International Society of Biorheology which was bestowed upon Maurice Joly at the Third International Congress of Biorheology, held at the University of California, San Diego, at La Jolla from August 27 to September 1, 1978.

The special issue contains many of the Proceedings of the Congress including a report by the Congress Chairman, Y.C. Fung. Among the Proceedings are the two Convocation Addresses by Bun'ichi Tamamushi and A.L. Copley, the Award Presentation Address by Syoten Oka and the Poiseuille Award Lecture by Maurice Joly. Since the Alcopley Art Exhibit was invited by the Congress Chairman as an activity of the Congress, a brief report on this exhibition together with the Preface to the exhibition catalogue by Y.C. Fung, are, therefore, included, as is my contribution on art and biorheology. This double issue contains also the address which R.L. Swank, The IIonorary Congress Chairman, gave at the Banquet.

The scientific program, the abstracts of communications and an author index comprised a volume of 245 pages, entitled "Proceedings of the Third International Congress of Biorheology". This volume, edited by Y.C. Fung and J.G. Pinto, was made available to the members of the Congress. Its contents are presented in this special issue to acquaint those of our Readers, who could not participate in this scientifically highly successful Congress, with new advances in our young and expanding science.

The accuracy of the abstracts, their form of citation, designation of materials, nomenclature and the like, all remain the responsibility of the authors. Readers should note that the appearance of these abstracts in this double issue does not necessarily imply future publication of their corresponding regular scientific papers in Biorheology. It should also be noted that future issues of our journal will contain additional Congress Papers. According to our editorial policy, their acceptance by any of our twelve Editors, to whom they have been submitted, will be based on the appraisals of two referees like that of Non-Congress Papers submitted to them.

In subsequent issues of Biorheology, Papers of the Congress Symposia,invited by their Chairmen, will be published after their acceptance by the respective Symposium Chairman who will act as Guest Editor if he is not an Editor of Biorheology. Subsequent issues of Biorheology will contain the Symposia as well as other accepted Congress Papers and Non-Congress Papers.

During the Congress, an Editorial Meeting took place which was sponsored by the Publishers of Biorheology. It was chaired by A.L. Copley and ten Editors participated. Editorial policies and practices were discussed at this meeting, as well as ways to increase contributions which will maintain the high standards of our journal and increase the circles of Readers and sub- 
scribers to Biorheology. At this meeting, our Editors found it more expedient and time saving to consider for publication in our journal Papers and Brief Communications only, if submitted to them in camera-ready form. Accordingly, our Instructions to Authors have been changed and communications will need to be submitted to an Editor of the Author's choice in camera-ready form. For the sake of rapid publication, the Publishers initiated an Executive Editorial office (EEO) under my direction at my New York address, where, beginning with the first issue in 1979, each issue will be assembled in the EEO and then forwarded to Pergamon Press for printing.

The generous support of the Publisher Mr. I.R. Maxwell and of Mr. G.F. Richards, Managing Director of Pergamon Press, in the publication of the Proceedings of this Congress was praised by the participants of this Editorial Meeting.

The letter of retirement as Co-Editor-in-Chief by Dr. George W. Scott Blair, addressed to the members of our Society, reached me only two days after the Editorial Meeting,just prior to the Convocation. It is published in this issue prior to the two Convocation Addresses. This issue also contains my tribute to my friend George W. Scott Blair.

In my two capacities as Editor-in-Chief of Biorheology and the Liaison Representative of the International Society of Biorheology with the Publishers I should like to thank Mr. Gilbert F. Richards and his associate, Mr. Michael J. Church, Managing Editor of Pergamon Press, for reserving this double issue entirely to the activities of the Third International Congress of Biorheology.

The assistance of Ms. Joan Laviscount and Ms. Regina Cherry-Kremer in the preparation of this special double issue is greatly appreciated.

Alfred L. Copley, Co-Editor-In-Chief 